Philosophical

Siblings 



\title{
Philosophical Siblings
}

Varieties of Playful Experience in Alice, William, and Henry James

Jane F. Thrailkill

\author{
$\overline{\text { PENN }}$ \\ UNIVERSITY OF PENNSYLVANIA PRESS \\ PH I L A D L P H I A
}


Copyright (C) 2022 University of Pennsylvania Press

All rights reserved. Except for brief quotations used for purposes of review or scholarly citation, none of this book may be reproduced in any form by any means without written permission from the publisher.

Published by

University of Pennsylvania Press

Philadelphia, Pennsylvania I9104-4II2 www.upenn.edu/pennpress

Printed in the United States of America on acid-free paper IO $9 \begin{array}{lllllllll} & 8 & 7 & 6 & 5 & 4 & 3 & 2 & \text { I }\end{array}$

Library of Congress Cataloging-in-Publication Data

Names: Thrailkill, Jane F., author.

Title: Philosophical siblings : varieties of playful experience in Alice, William, and Henry James / Jane F. Thrailkill.

Description: Philadelphia : University of Pennsylvania Press, [2022] | Includes bibliographical references and index. Identifiers: LCCN 202101536I | ISBN 978-0-8122-5332-0 (hardcover)

Subjects: LCSH: James, Alice, I848-1892. | James, William, I842-I910. | James, Henry, I843-1916. | Play (Philosophy) |

Play in literature. | Consciousness in literature.

Classification: LCC CT275.J278 T 47 2022 | DDC $973.092-\mathrm{dc2} 3$

LC record available at https://lccn.loc.gov/202101536I 
For Cathy Kerr, my brilliant friend

(1964-2016) 
